Olena Brintseva, $\mathrm{PhD}$ (Economics), Associate Professor, Kyiv National Economic University named after Vadym Hetman

(Kyiv, Ukraine) ORCID: 0000-0003-2442-3000

ResearcherID: G-2045-2017

\title{
CURRENT TRENDS IN THE DEVELOPMENT OF SOCIAL AND LABOR SPHERE IN UKRAINE
}

The paper examines the state of the social and labor sphere in Ukraine in 2004-2019. The Index of the state of the social and labor sphere is proposed, which will ensure timely tracking of the dynamics of its key parameters: average monthly wages; level of economic activity; the share of the population employed in the informal sector of the economy in the total number of the employed population; the share of workers who carry out work in conditions that do not meet sanitary and hygienic standards in the number of full-time employees. It is determined that the last 15 years have been quite complicated for Ukraine, it can even be argued that the crisis phenomena in all spheres of life were of a permanent nature.Asymmetries in the social and labor sphere of Ukraine do not provide sufficient opportunities for the productive use of human capital, while not providing sufficient resources for its reproduction. This leads to an increase in the migration processes, especially to the EU countries.

Key words: social and labor sphere, monitoring, economic losses, integration of labor markets.

Relevance of research topic. The question of the productive use of human capital as one of the most powerful factors of economic growth in the 21 st century is traditionally one of the most urgent. The processes of formation of both labor potential and development, use and preservation of human capital, we propose to consider the three-way system «education-health care, social and labor sphere». Within this system, the social and labor sphere provides productive use and financial resources for the processes of reproduction of human capital, the educational system - the processes of transfer of knowledge from generation to generation, the formation of the intellectual component of society, and the health care system - maintaining health and efficiency at proper level. Therefore, there is a logical question whether the current Ukraine 
is moving in the socio-economic development and whether there is now progress in human development. Is there an expansion of opportunities for the productive use of human capital, its development and preservation? In this study attention is focused on the processes that take place in the social and labor sphere in Ukraine, analyzes the dynamics of key indicators and asymmetries, which lead to a decrease in the efficiency of the use of human capital, and the deepening of the processes of digitization in this area.

Therefore, the purpose of this paper is to study the state of the social and labor sphere in Ukraine, as well as to develop the Index of the state of the social and labor sphere, which will ensure timely tracking of the dynamics of its key parameters.

\section{Formulation of the problem.}

In the context of development the Index of the state of the social and labor sphere, the following three aspects are crucial: the definition of the list of indicators that will be used as the basis for the calculation of the index, the base year for which the normalization of indicators is taking place and their subsequent change, as well as the method of calculation of the integral indicator from taking into account factorsstimulators and factors-de-stimulators.

Given the possibility of obtaining reliable and comparable data, as well as objective socio-economic conditions in the economy of Ukraine, as a basis it was select 2004. Then there was a certain improvement in the socio-economic situation in Ukraine, a certain expansion of the human capacity in the socio- the labor sphere. Thus, according to the proposed methodology of calculation, the dynamics of indicators of the social and labor sphere is researched in comparison with 2004; accordingly the achieved values of this year are the normalization of indicators. We propose to calculate the index of the state of the social and labor sphere as average geometric, taking into account the need to ensure adequate consideration of the influence of all indicators on the dynamics of the integral indicator. The proposed index combines the following indicators: average monthly wage, euro (stimulator); level of economic activity, \% (stimulator); the share of population employed in the informal sector of the economy in the total number of employed population, \% (destimulator); the share of workers who carry out work activities in conditions not complying with sanitary and hygiene standards, $\%$ to the number of registered staff (de-stimulator). In order to ensure comparability with other European countries, the average monthly salary in Ukraine is calculated in euro in accordance with the hryvnia rate in the period under investigation.It should be noted that the majority of employees of the informal sector of the economy are engaged in agriculture, hunting, forestry; fishing, fish farming. That is, they perform mostly simple, unskilled labor, which does not require the purposeful formation and accumulation of human capital. 
Consequently, the proposed Index of the state of the social and labor sphere $\left(\mathrm{I}_{\mathrm{SLS}}\right)$ is calculated according to the following formula:

$$
I_{S L S}=\sqrt[4]{I_{W} \times I_{E A} \times \frac{1}{I_{N E}} \times \frac{1}{I_{H C}}},
$$

where $I_{w}$ - basic growth rates of wages;

$I_{E A}$ - basic growth rates of economic activity;

$I_{N E}$ - is the basic growth rate of the population employed in the informal sector of the economy in the total number of the employed population;

$I_{H C}$ - is the basic growth rate of the share of workers who carry out work in conditions that do not meet sanitary and hygienic standards in the number of full-time employees. The last two indicators are de-stimulators and have an inverse effect on the dynamics of the Index of the state of the social and labor sphere.

\section{Analysis of recent researches and publications}

Current changes in the social and labour sphere and, accordingly, the development of researches in this area, occur in accordance with such global trends as digitalization, globalization processes, the integration of national labor markets and educational services. Experts of the «New Economy and Society Center» (World Economic Forum, 2018) conducted an on-line survey of companies and identified trends in the workforce for 2018-2022, most of which are directly related to the spread of information technology: rotation, change of geography of production, distribution and target chains; change in the types of employment under the influence of information technology; automation of business processes, reduction of the total number of working hours performed by people; employment transformation (the emergence and disappearance of occupations, jobs, increased demand for professions, which involve increased use of technologies - training automation specialists, experts in the analysis of large data, experts in process automation, information security analysts, user experience and human resources - designers interactions with machines, robotics engineers and blockers specialists), rapid obsolete skills and increased training needs for workers with the most greater risk of technological change. In addition, the study found that the driver of change that has a positive impact on business growth is four technological advances: widespread high-speed mobile Internet; Artificial Intelligence; widespread use of large analytical data; and «cloud» technologies.

The processes of transformation of the social and labor spherein the new, digital economy investigated by Bell (1973), Wallerstein (2004), Castel (2002), Kolot (2015), Lyashenko (2018) et al. 
The issues of transformation of the social and labor sphere and its monitoring are also indicated by other authors. Kassi and Lehdonvirta (2016) studied the labour markets are thought to be in the midst of a dramatic transformation, where standard employment is increasingly supplemented or substituted by temporary work mediated by online platforms. Significant changes in the global labor market and the spread of gig employment is also evidenced by the dynamics of the Online Labour Index, a new economic indicator that provides the online gig economy equivalent on conventional labour market statistics. It measures the utilization of online labour across countries and occupations by tracking the number of projects and tasks posted on online gig platforms in near-real time.As of December 2018 compared to December 2016, Online Labour Index increased by +19.6 percentage points, in some periods it was 139.8 (May 2017). It should be noted that the index is normalized so that 100 index points on the y-axis represents the daily average number of new projects in May 2016 (The iLabour Project, 2020). This indicates significant changes in the global labor market that must be considered now.

Thus, for the monitoring of the state of the social and labor sphere, it is important to construct an integral index that would take into account not only common indicators such as wages or economic activity, but also the problematic aspects of functioning of this market, such as the spread of informal employment, an increase in the proportion of workers who carry out work in harmful conditions. Important is also the consideration of modern trends, such as the gradual increase in the level of digitization of the economy.

\section{Presenting main material}

The study of the dynamics of the state of the social and labor sphere in accordance with the current trends in the labor market, was conducted in response to the evolutionary processes that were inherent to it. Speaking about the changes that have taken place in this field in Ukraine from the beginning of the 21st century, it is worth emphasizing firstly, the following trends (table 1).

Table 1

\section{Changes that took place in the social and labor sphere in Ukrainefrom the beginning of the XXI century to the present}

\begin{tabular}{|c|l|}
\hline Period & \multicolumn{1}{|c|}{ Trends in the social and labor sphere } \\
\hline $2000-2007$ & $\begin{array}{l}\text { Gradual economic growth and improved labor market performance: an increase } \\
\text { in average wages and the emergence of new vacancies due to the gradual } \\
\text { increase in the volume of service delivery and production of goods }\end{array}$ \\
\hline $2008-2009$ & $\begin{array}{l}\text { Reducing opportunities for productive employment, rising unemployment } \\
\text { against the background of the economic crisis }\end{array}$ \\
\hline
\end{tabular}




\begin{tabular}{|c|l|}
\hline Period & \multicolumn{1}{c|}{ Trends in the social and labor sphere } \\
\hline 2010-2013 & $\begin{array}{l}\text { Partial recovery of the economy after the crisis, gradual improvement of the } \\
\text { labor market situation. The gradual emergence of new professions and the } \\
\text { modification of existing ones under the influence of the digitalization of the } \\
\text { economy }\end{array}$ \\
\hline \multirow{2}{*}{$2014-2017$} & $\begin{array}{l}\text { Political, military, socio-economic crisis, which caused not only the reduction of } \\
\text { macroeconomic indicators, but also a significant deterioration of the situation on } \\
\text { the national labor market, the strengthening of migration trends. More and more } \\
\text { Ukrainian workers most often in the age of 26-45 are temporarily or } \\
\text { permanently employed in EU countries, mainlyin Poland, Germany, Czech } \\
\text { Republic and Italy. In these circumstances, the tendencies of digitization and } \\
\text { intellectualization of labor and new opportunities can't be fully realized in the } \\
\text { social and labor sphere }\end{array}$ \\
\hline from 2018 \\
to present & $\begin{array}{l}\text { Further introduction of digital technologies in all spheres of life. Gradual, albeit } \\
\text { very slow economic growth. High levels of political instability and } \\
\text { unpredictability }\end{array}$ \\
\hline
\end{tabular}

For Ukraine, the gradual spread of global trends is quite typical against the backdrop of a powerful national context, the main component of which is the strong influence of the crisis phenomena in the economy that is most strongly manifested from 2014 to present.

Crisis phenomena in the social and labor sphere cause the spread of such violations by employers (Kolot, 2012): dismissal for tendentious reasons (repeated failure to perform labor duties, inconsistency of competencies of the employee with existing requirements based on the results of attestation); coercion to release on his own volition instead of dismissal for a reduction in the number or state with payment of compensation; change in the terms of the employment contract (reduction of wages, reduction of expenses for creation of safe working conditions, re-appointment of an employment contract with a termless one); failure to pay or untimely payment of wages; incomplete calculation at the time of dismissal; the introduction of atypical working time schedules that meet the needs of employers; work above normal without pay or compensation.

In times of crisis for the country, a noticeable decrease in the indicatorsstimulators and the growth of indicators-destimulators (table 2).

Thus, the average wage is down by $-25.1 \%$ in 2009 compared to 2008 and $21.8 \%$ in 2015 compared to 2014; a decrease in employment by $-3,7$ percentage points in 2014 compared with 2013. And accordingly, under the influence of the crisis phenomena in the economy, in 2014, as compared to 2013, the share of the population employed in the informal sector of the economy in the general the number of the employed population by $+3,6$ percentage points. 


\section{Dynamics of indicators of social and labor sphere in Ukraine in 2004-2019}

\begin{tabular}{|c|c|c|c|c|}
\hline Year & $\begin{array}{c}\text { Average } \\
\text { monthly salary, } \\
\text { euro / month }\end{array}$ & $\begin{array}{c}\text { Employment } \\
\text { rate of the } \\
\text { population aged } \\
\text { 15-70 years, \% }\end{array}$ & $\begin{array}{l}\text { The share of the } \\
\text { population employed in } \\
\text { the informal sector of } \\
\text { the economy in the total } \\
\text { number of employed } \\
\text { population, } \%\end{array}$ & $\begin{array}{l}\text { The share of workers } \\
\text { who carry out work } \\
\text { in conditions not } \\
\text { complying with sanitary } \\
\text { standards, \% to the } \\
\text { number of registered } \\
\text { staff }\end{array}$ \\
\hline 2004 & 89,3 & 56,7 & 19,2 & 26,9 \\
\hline 2005 & 126,1 & 57,7 & 21,3 & 27,4 \\
\hline 2006 & 164,3 & 57,9 & 22,3 & 27,5 \\
\hline 2007 & 195,3 & 58,7 & 22,3 & 27,5 \\
\hline 2008 & 234,3 & 59,3 & 21,8 & 27,5 \\
\hline 2009 & 175,4 & 57,7 & 22,1 & 27,8 \\
\hline 2010 & 213,6 & 58,5 & 24,2 & 27,8 \\
\hline 2011 & 238,7 & 59,2 & 24,5 & 28,9 \\
\hline 2012 & 296,1 & $\begin{array}{l}59,7 \\
\end{array}$ & 24,1 & 28,9 \\
\hline 2013 & 309,3 & 60,3 & 21,5 & 29,5 \\
\hline 2014 & 221,4 & 56,6 & 25,1 & 29,5 \\
\hline 2015 & 173,1 & 56,7 & 26,2 & 28,9 \\
\hline 2016 & 183,2 & 56,3 & 24,3 & 28,9 \\
\hline 2017 & 236,8 & 56,1 & 22,9 & 28,4 \\
\hline 2018 & 276,0 & 57,1 & 21,6 & 28,4 \\
\hline 2019 & 362,6 & 59,3 & 21,3 & 28,4 \\
\hline
\end{tabular}

Source: State Statistics Service of Ukraine (2020).

The dynamics of the Index of the state of the socio-labor sphere is rather vividly reflects the impact of crisis phenomena on the sphere of labor, their cyclicality (Fig. 1).

The last 15 years have been quite complicated for Ukraine, it can even be argued that the crisis phenomena in all spheres of life were of a permanent nature. 


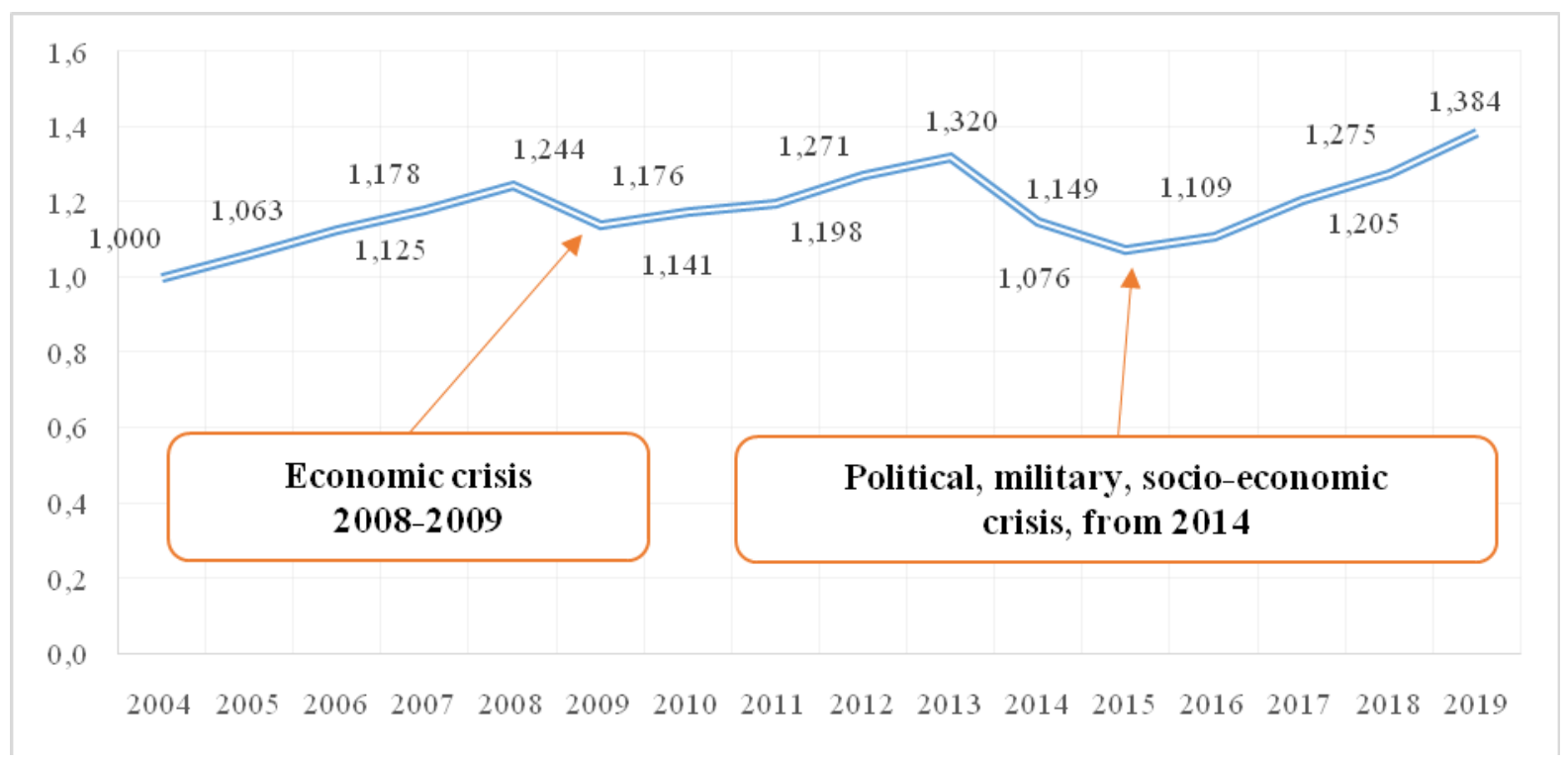

Fig. 1. Dynamics of the Index of the state of the socio-labor sphere in 2004-2019

\section{Conclusion}

Existing asymmetries in the social and labor sphere of Ukraine do not provide sufficient opportunities for the productive use of human capital, while not providing sufficient resources for its reproduction. This leads to an increase in the migration processes to other countries, especially the countries of the European Union such as Poland, Germany, Czech Republic.

In this context, it is obvious that for the labor markets of Ukraine, Poland, Germany and the Czech Republic there will be widespread integration, which is associated with objective reasons such as close geographic location, close socioeconomic and cultural ties, the possibility of building cooperation in the social and labor sphere on mutually beneficial grounds. However, for this purpose, many measures have yet to be taken to harmonize Ukrainian legislation with the legal norms of the EU countries, ensuring the maximum level of unity in socio-economic and cultural matters.

\section{REFERENCES}

1. Bell, D. (1973). The Coming of Post-Industrial Society: A Venture in Social Forecasting. New York: Basic Books.

2. Castel, R. (2002). The Metamorphosis of the Social Question. A Chronicle of Wage Labor. Konstanz: University Publishers. 
3. Kassi, O., Lehdonvirta V. (2016). Online Labour Index: Measuring the Online Gig Economy for Policy and Research. Oxford Internet Institute, Oxford Internet Institute. Retrieved from:https://mpra.ub.uni-muenchen.de/86627/8/ MPRA_paper_86627.pdf

4. Kolot, A.(2012). Asymmetries in the development of the social and labor sphere: manifestations, causes, preconditions for overcoming. Actual problems of economy. - No. 6 (132). - P. 205-211 (in Ukr.)

5. Kolot, A.,Kravchuk, O. (2015). Man and new economy: dialectics of development. Social-Labor Relations: Theory and Practice, 1(9), 8-29. Retrieved from http://nbuv.gov.ua/UJRN/stvttp_2015_1_3 (in Ukr.)

6. Lyashenko, V. (2018). Digital modernization of the Ukrainian economy as a possibility of breakthrough development: monograph. National Academy of Sciences of Ukraine, Institute of Industrial Economics (in Ukr.)

7. National Bank of Ukraine (2020). Official exchange rate of hryvnia against foreign currencies. Retrieved from: www.bank.gov.ua/files/Exchange_r.xls

8. State Statistics Service of Ukraine (2020). Official site. Retrieved from:http://www.ukrstat.gov.ua/

9. The iLabour Project (2020). Investigating the Construction of Labour Markets, Institutions and Movements on the Internet. The Online Labour Index. Retrieved from: http://ilabour.oii.ox.ac.uk/online-labour-index/

10. Wallerstein, I. (2004). End of the familiar world. Sociology of the XXI century: Monograph / I. Wallerstein. - Moscow: Logos (in Russ.).

11. World Economic Forum (2018). The Future of Jobs Report 2018. Insight Report. Retrieved from: http://www3.weforum.org/docs/WEF_Future_of_Jobs_2018.pdf 